(ㄱ Р. Л. Тріщук, асист., КПІ ім. Ігоря Сікорського, Київ, Україна

\title{
УЗАГАЛЬНЕНА ЛОГІЧНА СХЕМА МОДЕЛЮВАННЯ ПРОЦЕСІВ ТЕХНОЛОГІЧНОГО ЗАБЕЗПЕЧЕННЯ КОНТУРНОї СТАБІЛЬНОСТІ ПРИ ВИГОТОВЛЕННІ ІНТЕГРАЛЬНИХ ОБКЛАДИНОК
}

\section{Розроблено узагальнену логічну схему в параметричному} вигляді моделювання процесів технологічного забезпечення контурної стабільності обкладинок та якості й експлуатаційних властивостей деталей координувально-транспортувального блоку лінії для виготовлення інтегральних обкладинок з широкими клапанами.

Така схема дозволяє встановити взаємозв'язок між режимами комплексної технології оздоблювально-зміцнювальної обробки, геометричними і фізико-механічними параметрами поверхні циліндричних деталей координувально-транспортувального блоку лінії для виготовлення інтегральних обкладинок з широкими клапанами, визначити їх вплив на експлуатаційні характеристики поліграфічного обладнання та якість готової продукції.

Ключові слова: оздоблювально-зміцнювальна обробка; комплексний технологічний процес О30; логічна схема комплексної ОЗО; контурна стабільність обкладинок; інтегральна обкладинка.

\section{Постановка проблеми}

До важливих технологічних відкриттів сучасності у виготовленні книжкових конструкцій слід віднести інтегральну обкладинку. Зростання її частки на ринку та витіснення інших конструкцій книжкових оправ зумовлені рядом характеристик, до яких належать такі як: технологічність, міцність з'єднання, легкість виготовлення та низька собівартість. У свою чергу, при виготовленні сучасної книжкової продукції, зокрема інтегральних обклади- нок, які є її складовою частиною, за умов постійної конкуренції підвищуються вимоги до якості та термінів виготовлення кінцевого продукту. Дотримання цих вимог можливе при точній безперебійній тривалій роботі вузлів поліграфічного обладнання та, зокрема, їх рухомих деталей, які утворюють пари тертя та піддаються значним навантаженням у процесі експлуатації. Оскільки якість інтегральної обкладинки значною мірою залежить від точності її вихідних геометричних ха-

() Автор(и) 2020. Видавець КПІ ім. Ігоря Сікорського.

CC BY 4.0 (https://creativecommons.org/licenses/by/4.0/). 
рактеристик, виникає необхідність забезпечення високої зносостійкості та точності роботи деталей координувально-транспортувального механізму. Адже найменші відхилення в його роботі, які можуть бути спричинені зношуванням рухомих циліндричних деталей, призводять до проковзування та зміщення заготовок при подачі до фальцювально-склеювального блоку, i, як наслідок, відхилення фальців і нанесення клейового шару в непередбачених місцях негативно впливають на кінцеву якість обкладинки та продукції загалом.

До того ж, упродовж усього експлуатаційного терміну поліграфічного обладнання деталі вищезазначених вузлів постійно піддаються дії змінних циклічних навантажень і впливу агресивного середовища (паперовий пил, розчинники, клей, лак). Ці фактори спричиняють посилене зношування поверхонь тертя цих деталей.

Тому, зважаючи на специфіку роботи рухомих деталей поліграфічного обладнання в умовах тертя кочення, виникає необхідність підвищення їх строку служби та покращення критеріїв працездатності таких, як міцність, зносостійкість, корозійна стійкість. Крім цього, для забезпечення точності координування транспортувального механізму очевидною $€$ необхідність удосконалення циліндричних поверхонь його деталей шляхом модифікації їх геометричних параметрів для отримання оптимальної опорної площі контактування та формування складного мікрорельєфу, який унеможливить зсуви та проковзування заготовок.

\section{Аналіз попередніх досліджень}

Останнім часом у більшості досліджень не обмежуються одним з використовуваних нині методів поверхневої обробки, i, для досягнення необхідних властивостей поверхневих шарів деталей, застосовують комбінування технологічних процесів поверхневої обробки. Поєднання таких технологій дозволяє досягти більш високих показників якості поверхні за рахунок ширших можливостей варіювання параметрами на кожному етапі поверхневої обробки.

Так, у роботах [1-3] представлено комплексний технологічний процес утворення частково регулярного мікрорельєфу вібраційним обкатуванням поверхні з подальшим іï хромуванням. Запропонована технологія забезпечує значне підвищення зносостійкості циліндричних деталей поліграфічного обладнання. Але розроблена технологія не може в повній мірі забезпечити необхідну точність подачі паперу або картону при виготовленні обкладинок.

Спосіб обробки циліндричних поверхонь деталей поліграфічного обладнання у два етапи, описаний у [4, 5], передбачає утворення частково регулярного мікрорельєфу на першому етапі. Після цього, на другому етапі зменшують зусилля вдавлювання деформувального інструмента, а також інші параметри технологічного процесу та утворюють повністю регулярний мікрорельєф на циліндричній поверхні. Ця технологія підвищує зносостійкість деталей поліграфічного обладнання, але не за- 
безпечує подачу паперу при впровадженні її для валів лінії для виготовлення інтегральних обкладинок з широкими клапанами.

Згідно із запропонованою П. О. Киричком та О. І. Хмілярчук технологією утворення частково регулярного мікрорельєфу оздоблювально-зміцнювальною обробкою [6] на першому етапі оздоблювально-зміцнювальної обробки утворюють регулярний мікрорельєф чотирикутного типу. На другому етапі поверхню шліфують чашковим алмазноабразивним кругом. У результаті цієї операції знімаються напливи, утворені на першому етапі. Технологію утворення частково регулярного мікрорельєфу оздоблювально-зміцнювальною обробкою застосовують до пласких поверхонь деталей поліграфічного обладнання. Відсутність напливів не забезпечить стабілізацію подачі паперу.

Описана в [7] технологія утворення повністю регулярного мікрорельєфу на циліндричній поверхні деталі, яка здійснює обертання $з$ постійною швидкістю передбачає дві технологічні операції. На першій технологічній операції поверхневим пластичним деформуванням отримують повністю регулярний мікрорельєф на поверхні друкарського циліндра. На другій технологічній операції поверхню друкарського циліндра піддають хромуванню. Зазначена технологія підвищує зносостійкість друкарського циліндра у 2,5-2,8 рази та може збільшити площу контакту противідмарювальної пластини. Відхилення від круглості задовольняє технічні умови додрукарського циліндра. Водночас циліндрична поверхня з гексагональним мікрорельєфом не може покращити зчеплення з папером чи картоном під час його подачі при виготовленні інтегральних обкладинок 3 широкими клапанами.

Технології формування частково регулярного мікрорельєфу на циліндричних і пласких поверхнях оздоблювально-зміцнювальною обробкою подано в роботі [8]. Відносна площа мікрорельєфу, утворена регулярними нерівностями, знаходиться в межах 25 \%...30 \%. Розроблені технології використовуються для збільшення довговічності деталей у верстатобудівній і машинобудівній промисловості, а також для зменшення часу припрацювання та покращення плавності руху пар тертя.

Для обробки важкодоступних поверхонь деталей машин і механізмів розроблено технологію утворення мікрорельєфу, в якій використовується випромінювання двох лазерних установок [9]. Випромінювання основної лазерної установки зміцнює ділянки поверхні навколо мікролунок. Запропонована технологія покращує геометричні і фізикомеханічні параметри поверхні, а також зносостійкість деталі. Однак, упровадження цієї технології неможливе для цілеспрямованої подачі матеріалу для виготовлення обкладинок.

Проаналізувавши вищевказані технологічні процеси, для забезпечення точності координатного позиціювання палітурного матеріалу, а також підвищення експлуатаційних характеристик циліндричних рухомих деталей координувально-транспор- 
тувального блоку запропоновано триетапний технологічний процес оздоблювально-зміцнювальної обробки, який передбачає: на першому етапі утворення на поверхні деталей повністю регулярного мікрорельєфу, на другому - формування частково регулярного мікрорельєфу у вигляді поздовжніх заглибин, та наступну модифікацію приповерхневих шарів шляхом іонно-плазмового азотування на третьому етапі [10].

\section{Мета роботи}

Розробити узагальнену логічну схему моделювання технологічного забезпечення та взаємозв'язку якості й експлуатаційних властивостей деталей механізму координувально-транспортувального блоку лінії для виготовлення інтегральних обкладинок з широкими клапанами, а також показників якості обкладинок.

\section{Результати проведених досліджень}

Одним 3 найбільш важливих показників інтегральної обкладинки є контурна стабільність, яка характеризується відхиленням зовнішніх контурів від прямокутної побудови. Цей параметр формується під час проходження заготовки обкладинки через механізм координувальнотранспортувального блоку лінії для виготовлення інтегральних обкладинок. Зазначений показник залежить як від витратних матеріалів (папір, картон-хромерзац, клей, термоклей), так і від накладу та геометричних і фізико-механічних параметрів деталей координувально-транспортувального блоку, які контактують з обкладинкою.
Для встановлення взаємозв'язку з метою прогнозування, а в подальшому і керування не тільки контурною стабільністю, а й експлуатаційними властивостями деталей, розроблено узагальнену логічну схему моделювання процесів технологічного забезпечення контурної стабільності обкладинок та експлуатаційних властивостей циліндричних деталей (рис.).

На схемі наведено вплив комплексної технології оздоблювально-зміцнювальної обробки на експлуатаційні характеристики поліграфічного обладнання та якість кінцевої продукції.

На перших двох етапах комплексної обробки здійснюється послідовне формування складного мікрорельєфу [11] на оздоблювально-зміцнювальній установці, створеній на базі токарно-гвинторізного верстата 16К20. Такий комбінований мікрорельєф, утворений на поверхнях циліндричних деталей координувальнотранспортувального блоку лінії для виготовлення інтегральних обкладинок, забезпечує високу точність координатного позиціювання палітурного матеріалу при його переміщенні під час припресування та подальшого транспортування до фальцювально-склеювального блоку. Крім формування необхідних геометричних параметрів поверхні деталей відбувається підвищення їх міцнісних характеристик за рахунок стискувальних залишкових напруг, які виникають у результаті поверхневого пластичного деформування. Діапазон режимів формування регулярних мікрорельєфів на кожному з етапів комплексної обробки наведено у схемі (рис.). 


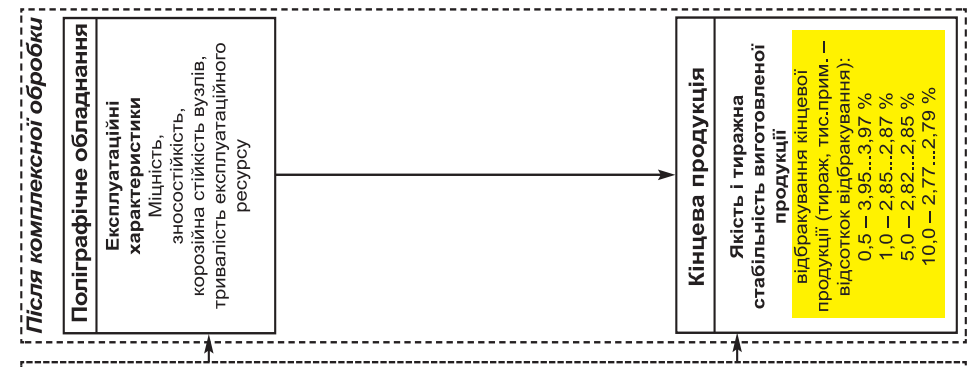

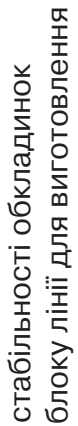
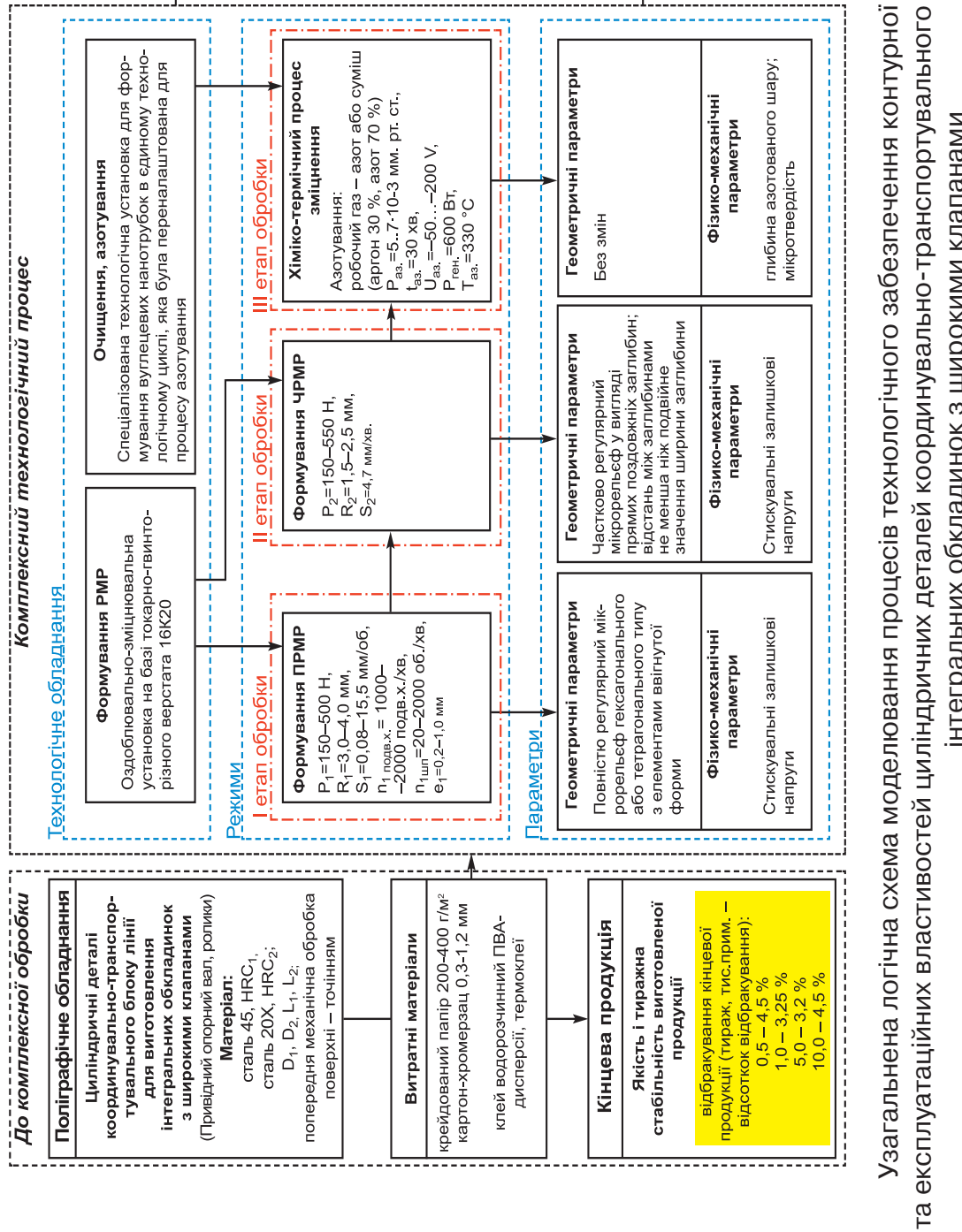
Завершальний, третій етап комплексного технологічного процесу оздоблювально-зміцнювальної обробки реалізується на спеціалізованій технологічній установці для формування вуглецевих нанотрубок в єдиному технологічному циклі, яка була переналаштована для процесу азотування. Після очищення деталі в середовищі аргону, без іiї вилучення з робочої камери установки, відбувається модифікація приповерхневих шарів цієї деталі шляхом насичення іонами азоту. При режимах обробки, вказаних на рис., досягається оптимальна глибина проникнення іонів азоту, що спричиняє утворення нітридів заліза в приповерхневих шарах деталі, обумовлюючи значне підвищення твердості поверхні. При цьому геометричні параметри поверхні залишаються без змін.

у результаті застосування комплексного технологічного процесу оздоблювально-зміцнювальної обробки одночасно забезпечується точність координатного переміщення палітурного матеріалу та підвищення експлуатаційних характеристик циліндричних деталей обладнання, таких, як міцність, зносостійкість, корозійна стійкість, тривалість експлуатаційного ресурсу. Усі вищезазначені фактори позитивно впливають на якість кінцевої продукції. Якісною кінцевою продукцією вважається готова інтегральна обкладинка, у якої паралельність відхилення зовнішніх контурів від прямокутної побудови не перевищує 0,2-0,5 мм на кожні 100 мм. Інакше обкладинка підпадає під відбраковування з подальшим її вилученням з накла- ду. На схемі (рис.) показано якість і тиражну стабільність виготовленої продукції до та після впровадження комплексного технологічного процесу оздоблювально-зміцнювальної обробки. Якщо без застосування цієї технології відсоток відбракування продукції становив 4,5 \%, 3,25 \%, 3,2 \% і 4,5\% відповідно для накладів 500, 1000, 5000 і 1000 примірників, то після реалізації комплексної обробки ці показники суттєво скоротилися до 3,95...3,97 \%, $2,85 \ldots 2,87 \%, 2,82 \ldots 2,85 \%$ та $2,77 \ldots 2,79 \%$ для аналогічних накладів.

Підвищення показників якості обкладинок характеризується істотним зменшенням відсотка їх відбракування після застосування комплексного технологічного процесу оздоблювальнозміцнювальної обробки. А це підтверджує доцільність застосування цього технологічного процесу.

\section{Висновки}

У результаті експериментальних і теоретичних досліджень для встановлення взаємозв'язку з метою прогнозування, а в подальшому і керування не тільки контурною стабільністю, а й експлуатаційними властивостями деталей, розроблено ефективну узагальнену логічну схему моделювання процесів технологічного забезпечення контурної стабільності обкладинок та експлуатаційних властивостей циліндричних деталей механізму координувально-транспортувального блоку лінії для виготовлення інтегральних обкладинок. Застосування цієї логічної схеми 
доцільне при комплексній обробці не тільки деталей лінії для виготовлення обкладинок, а й ін- шого поліграфічного обладнання, такого, як машини для флексографічного друку та ін.

\section{Список використаної літератури}

1. Лотоцька О. І. Підвищення експлуатаційних властивостей деталей поліграфічних машин / О. І. Лотоцька // Технологія і техніка друкарства. 2008. № 3-4. С. 16-20.

2. П. О. Киричок. Експериментальні дослідження геометричних параметрів циліндричних деталей поліграфічних машин при комплексній обробці / П. О. Киричок, О. І. Лотоцька // Технологія і техніка друкарства. 2011. № 3(33). C. 4-12. DOI: https://doi.org/10.20535/2077-7264.3(33).2011.52142.

3. Спосіб утворення регулярного мікрорельєфу: пат. № 55748 Україна: МПК В24В 39/00 / Киричок П. О., Лотоцька О. І.; заявник і патентовласник Національний технічний університет України «Київський політехнічний інститут». № u201006779; заявл. 01.06.2010; опублік. 27.12.2010, Бюл. № 24. C. 4.

4. Киричок П. О. Комплексна оздоблювально-зміцнююча обробка / П. О. Киричок, О. І. Хмілярчук // Технологія і техніка друкарства. 2005. № 3-4. С. 46-52.

5. Патент України UA 10734 А, МПК В24B39/00. Спосіб утворення мікрорельєфу / Киричок П. О., Хмілярчук О. I. № U200505560. Заявлено 10.06.05. Опубл. 15.11.05. Бюл. № 11.

6. Патент України № 18495, МПК В24В39/00. Пристрій для комбінованої обробки плоских поверхонь деталей / Киричок П. О., Хмілярчук О. І., Олійник В. Г. № u200604718; Заявл. 27.04.2006; Опубл. 15.11.2006, Бюл. № 11.

7. Спосіб утворення повністю регулярного мікрорельєфу на друкарських циліндрах: пат. № 81651 Україна: МПК B41N 10/00 B41N 7/00 / Киричок П. О., Зигуля С. М.; заявник і патентовласник Киричок П. О. № 201214875; заявл. 25.12.2012; опубл. 10.07.2013. Бюл. № 13. 16 с.

8. Патент України на корисну модель. Спосіб покращення експлуатаційних властивостей захватів аркушепередавальної системи аркушевих офсетних друкарських машин: пат. № 79894 Україна: МПК (2013.01) B41F 31/00, В41F 21/00, В41N 7/00. Несхозієвський А. В., Несхозієвська Т. М., Киричок П. О.; заявник і патентовласник Несхозієвська Т. М. № u 201210682; заявл. 12.09.2012; опублік. 13.05.2013, Бюл. № 9.

9. Киричок П. О. Оздоблювально-зміцнювальна обробка важкодоступних поверхонь / П. О. Киричок // Технологія і техніка друкарства. 2005. № 1(7). C. 95-98.

10. Киричок П. О. Підвищення експлуатаційних властивостей деталей лінії для виготовлення інтегральних обкладинок з широким клапаном / П. О. Киричок, Р. Л. Тріщук // Технологія і техніка друкарства. 2017. № 3(57). С. 4-19. DOI: https://doi.org/10.20535/2077-7264.3(57).2017.111523.

11. Пат. 129043 Україна, МПК (2006) В24В 39/00. Спосіб утворення регулярного мікрорельєфу на поверхнях циліндричних деталей поліграфічних машин / П. О. Киричок, Ю. Ю. Віцюк, Р. Л. Тріщук; заявник і власник Нтуу «КПІ ім. Ігоря Сікорського». № u201800825; заявл. 30.01.2018; опубл. 25.10.2018, Бюл. № 20. 6 с. 


\section{References}

1. Lototska, O. I. (2008). Pidvyshchennia ekspluatatsiinykh vlastyvostei detalei polihrafichnykh mashyn [Improving the Performance Properties of Parts of Printing Machines]. Journal of Tekhnolohiia i tekhnika drukarstva, 3-4, 16-20 [in Ukrainian].

2. Kyrychok, P. O. \& Lototska, O. I. (2011). Eksperymentalni doslidzhennia heometrychnykh parametriv tsylindrychnykh detalei polihrafichnykh mashyn pry kompleksnii obrobtsi [Experimental Studies of the Geometric Parameters of Cylindrical Parts of Printing Machines in the Time of Complex Processing]. Journal of Tekhnolohiia i tekhnika drukarstva, 3(33), 4-12. DOI: https://doi.org/10.20535/2077-7264.3(33).2011.52142 [in Ukrainian].

3. Kyrychok, P. O. \& Lototska, O. I. Sposib utvorennia rehuliarnoho mikroreliefu [The Method of Formation of a Regular Microrelief] // Patent № 55748 UA. Publish 27.12.2010 [in Ukrainian].

4. Kyrychok, P. O. \& Khmiliarchuk, O. I. (2005). Kompleksna ozdobliuvalnozmitsniuiucha obrobka [Complex Strengthening Finishing]. Journal of Tekhnolohiia i tekhnika drukarstva, 3-4, 46-52 [in Ukrainian].

5. Kyrychok, P. O. \& Khmiliarchuk, O. I. Sposib utvorennia mikroreliefu [The Method of Microrelief Formation] // Patent №U200505560 UA. Publish 15.11.05 [in Ukrainian].

6. Kyrychok, P. O. \& Khmiliarchuk, O. I. \& Oliinyk, V. H. Prystrii dlia kombinovanoi obrobky ploskykh poverkhon detalei [Device for Combined Processing of Flat Surfaces of Parts] // Patent № u200604718 UA. Publish 15.11.2006 [in Ukrainian].

7. Kyrychok, P. O. \& Zyhulia, S. M. Sposib utvorennia povnistiu rehuliarnoho mikroreliefu na drukarskykh tsylindrakh [Method of Forming Completely Regular Microrelief on Printing Cylinders] // Patent № 201214875 UA. Publish 10.07.2013 [in Ukrainian].

8. Neskhoziievskyi, A. V. \& Neskhoziievska, T. M. \& Kyrychok, P. O. Sposib pokrashchennia ekspluatatsiinykh vlastyvostei zakhvativ arkusheperedavalnoi systemy arkushevykh ofsetnykh drukarskykh mashyn [The Method of Improving the Performance of the Grips of the Sheet-Fed Transmission System of SheetFed Offset Printing Machines] // Patent № u201210682 UA. Publish 13.05.2013 [in Ukrainian].

9. Kyrychok, P. O. (2005). Ozdobliuvalno-zmitsniuvalna obrobka vazhkodostupnykh poverkhon [Finishing and Strengthening Treatment of Hard-to-Reach Surfaces]. Journal of Tekhnolohiia i tekhnika drukarstva, 1(7), 95-98 [in Ukrainian].

10. Kyrychok, P. O. \& Trishchuk, R. L. (2017). Pidvyshchennia ekspluatatsiinykh vlastyvostei detalei linii dlia vyhotovlennia intehralnykh obkladynok z shyrokym klapanom [Operational Properties Improving of Line Parts for the Production of Flexible Covers with a Wide Valve]. Journal of Tekhnolohiia $i$ tekhnika drukarstva, 3(57), 4-19. DOI: https://doi.org/10.20535/20777264.3(57).2017.111523 [in Ukrainian].

11. Kyrychok, P. O. \& Vitsiuk, Yu. Yu. \& Trishchuk, R. L. Sposib utvorennia rehuliarnoho mikroreliefu na poverkhniakh tsylindrychnykh detalei polihrafichnykh mashyn [Method of Forming Regular Microrelief on Surfaces of Cylindrical Parts of Printing Machines] // Patent № u201800825. Publish 25.10.2018 [in Ukrainian]. 
The generalized logical scheme in parametric form of modeling of processes of technological maintenance of contour stability of covers and quality and operational properties of details of the coordinating and transporting block of the line for production of integrated covers with wide valves is developed. This scheme allows to establish the relationship between the modes of complex technology of finishing and strengthening, geometric and physical and mechanical parameters of the surface of the cylindrical parts of the coordination and transport unit of the line for the manufacture of integrated covers with wide valves, to determine their impact on printing performance and quality of finished products.

Keywords: finishing and strengthening treatment; complex technological process of FST; logical scheme of complex FST; contour stability of covers; integral cover.

Рецензент - А. І. Іванко, канд. техн. наук, доц., КПІ ім. Ігоря Сікорського 